fishing per somewhat longer voyage and more fish per day at sea and per ton of fuel.

These two British pioneer experiments have indicated two possible ways of improving the exploitation of wide-ranging fisheries. 'Those who rely on supplies brought in by distant-water trawlers may before very long be freezing sizeable quantities at sea' (European Productivity Agency of the Organisation for European Economic Co-operation, 1957, p. 38).

This paper was prepared as part of the programme of the Food Investigation Organization, Department of Scientific and Industrial Research. (Crown Copyright Reserved.)

\title{
REFERENCES
}

Anonymous (1957a). Ship \& Boat Build. 10, 352

Anonymous (1957b). Ship \& Boat Build. 10, 472 .

Barthel, F. (1956). Ship \& Boat Build. 9, 195.

Cutting, C. L., Eddie, G. C., Reay, G. A. \& Shewan, J. M. (1953). Leafl. Food Invest. Bd, no. 3, 3rd ed.

Ducroz, J. (1957). Rev. Elev. I0, I47.

Eddie, G. C., Hales, R. T. \& Higham, D. W. (1957-8). Proc. Inst. Refrig. (In the Press.)

European Productivity Agency of the Organisation for European Economic Co-operation (1957). Fish Marketing in Western Europe Since 1950. Paris: European Productivity Agency of the Organisation for European Economic Co-operation.

Food and Agriculture Organization of the United Nations (1955). Yearb. Fish. Statist. F.A.O. 4, Part 2.

Food and Agriculture Organization of the United Nations (1957a). Yearb. Fish. Statist. F.A.O. 6.

Food and Agriculture Organization of the United Nations (1957b). The State of Food and Agriculture, p. 59. Rome: Food and Agriculture Organization of the United Nations.

Hardy, A. C. (1952). Fish. News, Aberd., no. 2024, p. 10.

Harrison, J. S. M. \& Roach, S. W. (1954). Progr. Rep. Pacif. biol. Sta. no. 100, p. 13.

Harrison, J. S. M. \& Roach, S. W. (1955). Progr. Rep. Pacif. biol. Sta. no. ro4, p. 3.

Harrison, J. S. M. \& Roach, S. W. (1957). Progr. Rep. Pacif. biol. Sta. no. 108, p. 10.

Ingram, M., Barnes, E. M. \& Shewan, J. M. (1956). Food Sci. Abstr. 28, 121.

Lochridge, W. (1955-6). Trans. Instn Engrs Shipb. Scot. 99, 5 I 1.

Partmann, W. (1957). Z. LebensmittUntersuch. 106, 2 I0.

Pearson, S. F. (1958). Private communication.

Reay, G. A., Banks, A. \& Cutting, C. L. (I950). Leafl. Food Invest. Bd, no. I I.

Schmidt, P. J. \& Idler, D. R. (1955). Progr. Rep. Pacif. biol. Sta. no. 104, p. 9.

Shewan, J. M. (1956). Fish. News, Aberd., no. 2260, p. 10.

Shewan, J. M. (1958). Rep. Progr. appl. Chem. (In the Press.)

Steiner, G. \& Tarr, H. L. A. (1955). Progr. Rep. Pacif. biol. Sta. no. 104, p. 7.

Tarr, H. L. A. (1956). In Proceedings First International Conference on the Use of Antibiotics in Agriculture, p. I99. Washington: National Academy of Sciences-National Research Council.

Thode, H. \& Hecht, W. (I954). Hansa, 91, 1767.

White Fish Authority (1957a). Sixth Annual Report. London: H.M. Stationery Office.

White Fish Authority (1957b). Report on an Experiment into the Freezing of Fish at Sea. London: White Fish Authority.

\section{Fish meal in livestock feeding}

\section{By A. A. Woodham, Rowett Research Institute, Bucksburn, Aberdeenshire}

Of the fish meal manufactured in the United Kingdom from both white fish and herring the greater portion is utilized for animal feeding, a very small proportion only of low-grade meal being used as a fertilizer, Non-ruminant farm animals and 
poultry are the chief consumers, and fish meal with meat and whale products forms a principal source of the animal protein needed for the supplementation of their cereal rations. Such is the demand for this purpose that the supply of homeproduced material has become increasingly inadequate in recent years.

Table r. Home consumption of fish meal 1950-6 (thousands of tons)

\begin{tabular}{|c|c|c|c|c|c|c|}
\hline \multirow[b]{2}{*}{ Year } & \multicolumn{2}{|c|}{ Home production } & \multicolumn{2}{|c|}{ Imports } & \multirow[b]{2}{*}{$\begin{array}{c}\text { Total } \\
\text { home } \\
\text { production }\end{array}$} & \multirow[b]{2}{*}{$\begin{array}{l}\text { Total } \\
\text { imports }\end{array}$} \\
\hline & $\begin{array}{l}\text { White-fish } \\
\text { meal }\end{array}$ & $\begin{array}{c}\text { Herring } \\
\text { meal }\end{array}$ & $\begin{array}{l}\text { White-fish } \\
\text { meal }\end{array}$ & $\begin{array}{c}\text { Herring } \\
\text { meal }\end{array}$ & & \\
\hline r950 & N.I. & 5 & N.I. & N.I. & $5^{8}$ & I 8 \\
\hline 1951 & N.I. & 6 & N.I. & N.I. & 75 & N.I. \\
\hline 1952 & 66 & 6 & N.I. & N.I. & 72 & N.I. \\
\hline 1953 & 65 & 19 & 29 & 30 & 84 & 59 \\
\hline I954 & 68 & 14 & 37 & 46 & $8 z$ & 83 \\
\hline 1955 & 77 & 13 & 35 & 56 & 90 & $9 \mathrm{I}$ \\
\hline 1956 & 79 & 6 & N.I. & N.I. & 85 & 108 \\
\hline
\end{tabular}

In $195^{\circ}$ less than one-quarter of the total fish meal used in this country was imported. The proportion has increased steadily over the past 7 years and, although home production has itself risen by nearly 50\%, the amount imported in 1956 exceeded home production by $25 \%$. Fish meal has always been preferred to meat or whale meal as a source of animal protein, and during the period between 1950 and 1956 it has consistently formed $60 \%$ of the total consumption of animal byproducts in this country. As home production has been unable to meet the demand, this proportion has been maintained at the cost of ever-increasing imports. (See Table I.)

In the light of these facts it is obviously to the advantage of the country as a whole that the optimum use should be made of the fish meal available from home production and further that every effort should be made to increase this production. Waste may be avoided by the omission of fish meal from rations where experiment has shown that no advantage is to be gained by its inclusion, and by ensuring that it is never used at excessive levels.

Though condemned fish and unsaleable fish are both converted into fish meal, by far the largest source is fish offals, guts excluded. The efficient organization of the collection of filleting waste at ports and from fishmongers' premises is one obvious way of providing more raw material for fish-meal production and, in fact, the increased home production of white-fish meal since 1953 has been due entirely to increased processing of offals. (See Table 2.)

Table 2. Sources of home-produced white-fish meal

\begin{tabular}{ccccc}
\multicolumn{4}{c}{ Raw material (thousands of tons) } & Total home production \\
of white-fish meal \\
Year & $\begin{array}{c}\text { Condemned } \\
\text { fish }\end{array}$ & $\begin{array}{c}\text { Unsaleable } \\
\text { fish }\end{array}$ & Offals & $\begin{array}{c}\text { (thousands of tons) } \\
1953\end{array}$ \\
1956 & 6.3 & 26 & 245 & 65 \\
1956 & 27 & 292 & 79
\end{tabular}


The current practice of gutting at sea, with subsequent discarding overboard of the waste, results in the loss of a significant amount of material that could yield feeding meal. Attempts to encourage the retention of it in recent years have met with little success. The rapid decomposition of fish guts and the increased refrigerating costs, as well as the inconvenience of storage on vessels that are not suitably equipped, all contribute to the continuation of this wasteful practice.

No increase in the quantity of condemned fish is either desirable or likely, and the remaining alternative is the catching of fish solely for the purpose of meal production. Obviously fresh fish destined for meal production must be surplus to human requirements or of types not normally eaten. There would be no excuse nutritionally or economically for the diversion of first-class protein material to animal feeding, resulting in the production of a much smaller quantity of protein with no greater nutritive value. The value of whole fish to be used for reduction would not need to exceed greatly $£$ ro/ton, the current price of fish offals, and such a low return does not give encouragement to the project. The effect of such a scheme upon supplies of fresh fish for human consumption must also be considered. Any tendency to increase the price of such supplies is patently undesirable. This country is not advantageously placed as regards supplies of fish of types suitable only for meal. The United States has easy access to menhaden, for example, but the most feasible proposition for British fisheries involves trawling for redfish in distant waters. Unfortunately the present subsidy system strongly favours the inshore seine-net vessels, so much so that landings by these vessels since $195^{\circ}$ has increased by ten times the corresponding increase for trawlers. The easy terms of the grant and loan scheme for the purchase of seine-net vessels add to the difficulty, and it seems that under present conditions it cannot be economic for trawlers to undertake voyages of long duration to distant waters to catch fish for reduction to meal for only a fraction of the return obtained by inshore fishermen for good-quality white fish. Though it is possible that the problem may be eventually resolved, it has been apparent for a number of years and we seem now to be very little nearer a solution.

\section{The place of fish meal in livestock feeding}

In view of the position with regard to supplies of white-fish meal it is natural that the possibility of replacement by alternative sources of protein should be carefully considered. Whereas fish meal has steadily increased in price during the last 4 years, oilseed meals have become very much cheaper during the same period. At the beginning of 1954 white-fish meal and groundnut meal cost $f_{4} 7 \mathrm{I}$ and $f_{442} /$ ton respectively but the corresponding current prices are $f_{0} 6$ and $£ 33 /$ ton. To what extent then can white-fish meal be replaced by vegetable proteins? Of course, the exchange value must be reckoned not merely in money: the different ability of oilseed meals to supply essential growth requirements must be allowed for on the basis of scientific experiment. White-fish meal is currently used primarily in rations for pigs and poultry, and reports of recent work are available upon which comparisons may be made and conclusions drawn regarding the extent to which alternative protein sources can be substituted for fish meal. 
Work at Cambridge on the feeding of bacon pigs (Woodman \& Evans, 1948, 195 I ; Evans, 1952) demonstrated in the first place that supplementation with protein concentrates was needed only between weaning and $90 \mathrm{lb}$. live weight and, further, that optimum performance was obtained when a ration composed principally of barley and fine bran was supplemented with $7 \%$ white-fish meal. Increasing the fish meal beyond this level brought about no further improvement. The effect of substituting various levels of groundnut and soya-bean meals for the fish meal was examined, and it was concluded that $20 \%$ of the former or $15 \%$ of the latter gave equivalent results. It was also concluded that mixtures of fish meal and groundnut meal could be used, thus effecting greater economy, and it was originally claimed that $2 \%$ of fish meal with $6 \%$ of groundnut meal was equivalent to the $7 \%$ fish-meal control ration. This assessment may be optimistic and it was in fact shown that such rations gave somewhat poorer growth rates than a $7 \%$ fish-meal ration (Carpenter, Duckworth, Lucas, Shrimpton \& Walker, 1956). A safer mixture would include $3 \%$ fish meal with $6 \%$ groundnut. Doubt has also been expressed regarding the equivalency of an all-vegetable ration containing $20 \%$ groundnut, and it seems likely now that even unlimited groundnut would not replace $7 \%$ fish meal entirely adequately.

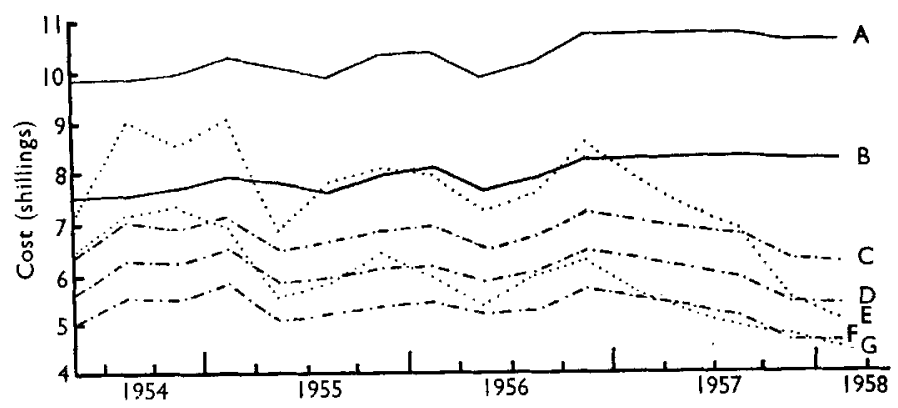

Fig. I. Comparative cost of supplements only for pig rations from 1954 to 1958 . The figures represent the total cost/pig after adjustment for cereals replaced.

$\mathrm{A}, 7 \%$ white-fish meal to $90 \mathrm{lb}$. live weight with subsequent stepped reduction to 5,3 and $\mathrm{I} \%$ up to $\mathrm{r} 20 \mathrm{lb}$. live weight; $\mathrm{B}, 7 \%$ white-fish meal to $90 \mathrm{lb}$. live weight; $\mathrm{C}, 4 \%$ white-fish meal and $6 \%$ groundnut meal; D, $3 \%$ white-fish meal and $6 \%$ groundnut meal; E, $20 \%$ groundnut meal; F, $2 \%$ white-fish meal and $6 \%$ groundnut meal; G, $15 \%$ soya-bean meal.

Fig. I records the fluctuation in cost during the last 4 years of the various levels of supplementation used by Woodman \& Evans (1948) with, in addition, three other possible variations that have been proposed. It will be seen that the trends in prices already mentioned have rendered a $7 \%$ fish-meal supplement quite uneconomic in comparison with oilseed meals given alone or in admixture with small proportions of fish meal. In view of the doubts attaching to an all-groundnut supplement or to a $6 \%$ groundnut and $2 \%$ fish-meal supplement, the choice lies between $3 \%$ fish meal and $6 \%$ groundnut meal and an all-vegetable supplement consisting of $15 \%$ soya-bean meal. Although at present the latter is somewhat cheaper, there was little difference in price between the two throughout 1955 and 1956 . 
A comparison of standard fish-meal rations for poultry with possible all-vegetable alternatives has been made at the Rowett Research Institute. Chicks fed for their first 6 weeks of life on a ration containing $17.5 \%$ groundnut meal, followed by a reduced level of $13 \%$ groundnut meal to point of lay, fared no worse than birds fed on a ration which conformed to the existing regulations of the Ministry of Food, containing $7 \cdot 5 \%$ white-fish meal with $7 \%$ groundnut meal for the first 6 weeks and $2.5 \%$ white-fish meal with $9.5 \%$ groundnut thereafter (Carpenter \& Duckworth, I95I).

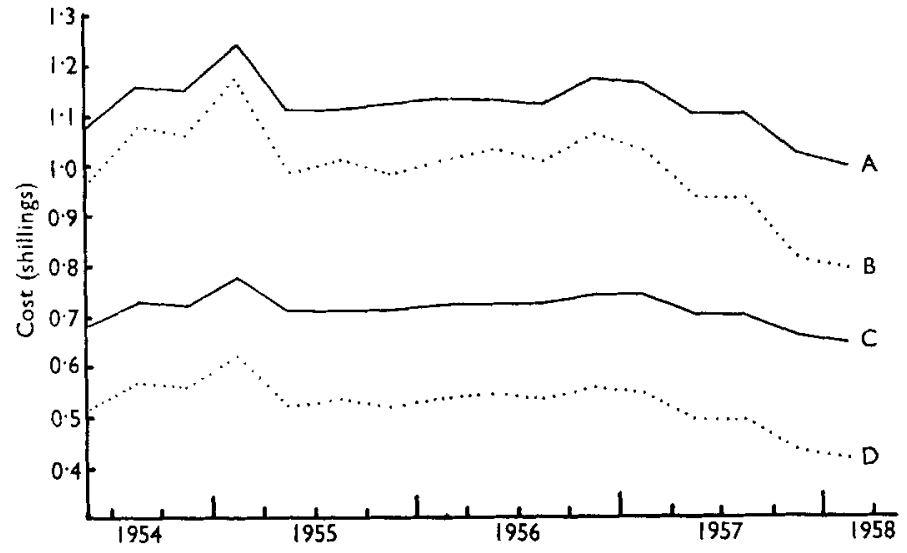

Fig. 2. Comparative cost of supplements for chicks from hatching to 21 weeks from 1954 to $195^{8}$ The figures represent the total cost/bird after adjustment for dietary components replaced.

A, $7.5 \%$ white-fish meal and $9 \%$ groundnut meal to 6 weeks followed by $2.5 \%$ white-fish meal and $9.5 \%$ groundnut meal to 21 weeks (pullets only); B, $17.5 \%$ groundnut meal to 6 weeks followed by $13 \%$ groundnut meal to 21 weeks (pullets only); $C$, the same ration as $A$ to 12 weeks (cockerels and pullets); $D$, the same ration as $B$ to 12 weeks (cockerels and pullets).

Fig. 2 shows the considerable economic advantage of the all-vegetable ration, both at 12 weeks, up to which time cockerels as well as pullets are considered, and at 21 weeks. It appears that at no time during the last 4 years has it been economic to include fish meal in either starting or growing rations for chicks and, furthermore, the price margin has been steadily increasing.

With laying birds, however, and especially those housed indoors, the attempt to replace fish meal economically has not been successful. Equivalent performance to that given with a ration conforming to the Ministry of Food requirements of that time, containing $7 \%$ fish meal and $14.5 \%$ crude protein, was obtained with either a ration containing $14 \%$ crude protein, $8.8 \%$ groundnut meal and no fish meal whatsoever, or with a ration containing $11 \%$ crude protein and $5.1 \%$ whitefish meal (Carpenter, Duckworth \& Ellinger, 1954). An all-vegetable ration containing only $1 \mathrm{I} \%$ crude protein was found to be inadequate, and it will be seen from Fig. 3 that the additional cost of providing the extra $3 \%$ protein renders the ration with the all-vegetable supplement uneconomic.

Experiments carried out in the United States during recent years have indicated the value of supplementing fish meal with DL-methionine in practical broiler 


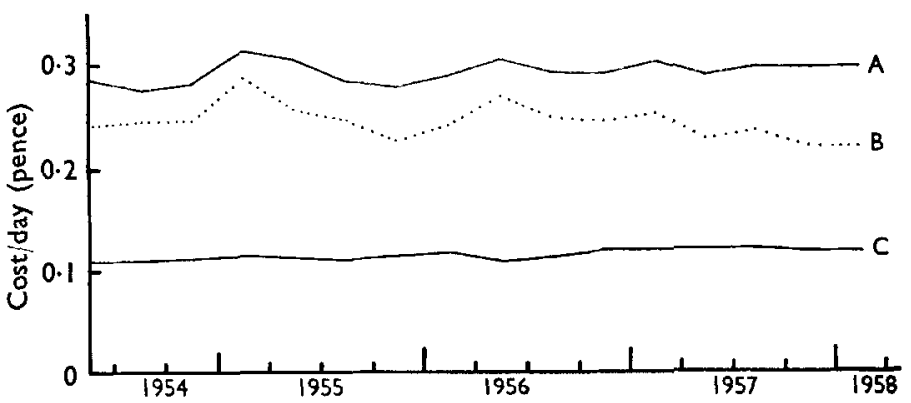

Fig. 3. Comparative cost of supplements for laying pullets from 1954 to 1958 . The figures represent the cost/bird/day for supplements only after adjustment for cereals replaced.

A, $7 \%$ white-fish meal in a ration containing $14.5 \%$ total protein; $\mathrm{B}, 8.8 \%$ groundnut meal in a ration containing $14 \%$ total protein; $\mathrm{C}, 5.1 \%$ white-fish meal in a ration containing $11 \%$ total protein.

rations. Rosenberg, Waddell \& Baldini (r955) found, for example, that the addition of free DL-methionine to diets of maize and soya-bean meal containing $5-15 \%$ fish meal, and apparently already possessing adequate methionine for normal growth, produced a significant increase in weight gain and food utilization in chick starters. Similar work on British types of ration is, however, lacking, and it is impossible to estimate the extent to which such supplementation with the pure amino-acid might be economical here. DL-methionine is now readily available and comparatively cheap, and it is certainly conceivable that a worth-while saving in white-fish meal could be realized.

It should be emphasized that the possibility of replacing fish meal is suggested mainly because of the inadequacy of home supplies. There is no doubt of the value of fish meal in rations for young animals, birds and sows, and providing that price allows, it should be included.

\section{REFERENCES}

Carpenter, K. J. \& Duckworth, J. (195I). F. agric. Sci. 4I, 297.

Carpenter, K. J., Duckworth, J. \& Ellinger, G. M. (1954). F. agric. Sci. 44, 340.

Carpenter, K. J., Duckworth, J., Lucas, I. A. M., Shrimpton, D. H. \& Walker, D. M. (I956). f. agric. Sci. 47, 435.

Evans, R. E. (1952). F. agric. Sci. 42, 438 .

Rosenberg, H. R., Waddell, J. \& Baldini, J. T. (1955). Poult, Sci. 34, 114.

Woodman, H. E. \& Evans, R. E. (I948). F. agric. Sci. 38, 5 I.

Woodman, H. E. \& Evans, R. E. (I95I). F. agric. Sci. 41, I02.

\section{Some consumer aspects of fish as food}

By C. L. Cutring, Humber Laboratory, Department of Scientific and Industrial Research, Hull

Fish consumption varies widely from $45 \mathrm{~kg} / \mathrm{head} /$ year in the Philippines and other islands of eastern Asia to less than $\mathrm{I} \mathrm{kg}$ in parts of central Europe and other inland areas (Food and Agriculture Organization o he United Nations, I949; Cutting, 